\title{
BUDAYA DAN MANAJEMEN KINERJA
}

\author{
Diksi Metris', Fadhilah Izhari² \\ ${ }^{1}$ Magister Manajemen, Fakultas Ekonomi, Universitas Muhammadiyah Jakarta \\ ${ }^{2}$ Magister Manajemen, Fakultas Ekonomi, Universitas Muhammadiyah Jakarta \\ '1diksi.metris@gmail.com; ${ }^{2}$ fadhilahizhari@yahoo.co.id
}

\begin{abstract}
ABSTRAK
Perkembangan kendaraan bermotor sebagai sarana transportasi di Indonesia saat ini menunjukkan pertumbuhan yang cukup pesat karena hampir setiap kebutuhan orang tidak terlepas dari sarana transportasi sebagai moda dalam kegiatan sehari-hari. Hal ini menciptakan peluang bisnis yang besar bagi dunia asuransi kerugian, khususnya asuransi kendaraan bermotor. Hal ini terkait dengan semakin tingginya risiko yang akan dihadapi oleh para pemilik kendaraan bermotor. Disisi lain pesatnya perkembangan teknologi saat ini, menuntut perusahaan untuk dapat berubah mengikuti perkembangan yang ada. Perubahan ini menuntut perusahaan untuk mampu beradaptasi terhadap perubahan yang ada. Hal yang harus dilakukan perusahaan untuk tetap bertahan dan berkembang adalah dengan mempelajari budaya, perubahan lingkungan strategik dan beradaptasi pada perubahan itu. Kebutuhan sumber daya manusia yang kompeten yang memiliki semangat, kedisiplinan, dan integritas yang baik sangat diperlukan untuk mencapai tujuan perusahaan. Dengan budaya organisasi yang baik dan manajemen kinerja yang baik akan dapat menciptakan sumber daya yang berkualitas. Penelitian ini bertujuan untuk mengetahui sejauh mana penerapan budaya perusahaan dalam menunjang manajemen kinerja surveyor. Metode penelitian ini menggunakan metode kualitatif dengan pendekatan naratif, yang memiliki karakteristik alami (natural setting) sebagai sumber data langsung, deskriptif. Hasil dari penelitian ini menunjukkan keberhasilan manajemen kinerja karyawan hampir selalu dikaitkan dengan budaya yang kuat. Berdasarkan analisa SWOT yang dilakukan, maka salah satu strategi yang perlu dijalankan oleh Asuransi Astra Buana adalah memanfaatkan budaya perusahaan yang baik dan kemampuan SDM yang dimiliki untuk menghasilkan layanan yang terbaik pagi pelanggan dan juga meningkatkan kinerja surveyor. Semakin banyak anggota organisasi menerima nilai-nilai tersebut secara positif, maka akan semakin kuat budaya perusahaan dan semakin menambah kinerja karyawan. Penerapan visi, misi, budaya perusahaan, strategi layanan, dan tata nilai perusahaan yang baik ini merupakan perwujudan dari penerapan manajemen sumber daya manusia yang telah dijalankan dengan baik di PT. Asuransi Astra Buana dan dapat menunjang manajemen kinerja Surveyor.
\end{abstract}

Kata Kunci: budaya perusahaan; manajemen kinerja; surveyor.

\begin{abstract}
The development of motorized vehicles as a means of transportation in Indonesia is currently showing a fairly rapid growth because almost everyone's needs cannot be separated from the means of transportation as a mode of daily activities. This creates great business opportunities for the world of general insurance, particularly motor vehicle insurance. This is related to the higher risk faced by motor vehicle owners. On the other hand, the rapid development of technology today requires companies to be able to change according to existing developments. This change requires companies to be able to adapt to existing changes. What a company must do to stay afloat and develop is to study culture, changes in the strategic environment and adapt to these changes. The need for competent human resources who have good enthusiasm, discipline and integrity is essential to achieve the company's goals. With a good organizational culture and good performance management will be able to create quality resources. This study aims to determine the extent to which the implementation of
\end{abstract}


corporate culture in supporting the surveyors' performance management. This research method uses a qualitative method with a narrative approach, which has natural characteristics (natural setting) as a direct, descriptive data source. The results of this study indicate that the success of employee performance management is almost always associated with a strong culture. Based on the SWOT analysis carried out, one of the strategies that Astra Buana Insurance needs to implement is to take advantage of a good corporate culture and the ability of its human resources to produce the best service for customers and also to improve surveyor performance. The more members of the organization accept these values positively, the stronger the company culture will be and the more employee performance will be. The implementation of the vision, mission, corporate culture, service strategy and good corporate values is a manifestation of the implementation of human resource management that has been carried out well at PT. Asuransi Astra Buana and can support Surveyor performance management.

Key Words: company culture; work management; surveyor

\section{A. PENDAHULUAN}

Pertumbuhan sarana transportasi di Indonesia saat ini menunjukkan peningkatan yang cukup pesat karena hampir di setiap aktifitas, manusia tidak terlepas dari sarana transportasi sebagai moda dalam kegiatan sehari-hari. Vice President Corporate Development PT. Pertamina Lubricants, Mohamad Zuchi menyampaikan mengutip data Badan Pusat Statistik:

“...jumlah kepemilikan kendaraan beroda empat di Indonesia tahun 2018 mencapai 24,6 juta. Masing-masing 15,8 juta untuk mobil penumpang, serta 8,8 juta untuk bus dan truk." (https://m.viva.co.id/amp/otomotif/motor/112 9068-jumlah-motor-di-indonesia-separuhpopulasi-penduduknya)

Hal ini menciptakan peluang bisnis yang besar bagi dunia asuransi kerugian, khususnya bagi asuransi kendaraan bermotor. Semakin banyak masyarakat yang ingin mengasuransikan kendaraannya, hal ini terkait dengan semakin tingginya risiko yang akan dihadapi oleh para pemilik kendaraan. Semakin banyak masyarakat menggunakan kendaraan bermotor untuk berpergian baik di dalam kota, maupun keluar kota.

Disisi lain pesatnya perkembangan teknologi saat ini, menuntut perusahaan untuk dapat berubah mengikuti perkembangan yang ada. Perubahan ini menuntut perusahaan untuk mampu beradaptasi terhadap perubahan yang ada.

Asuransi Astra adalah perusahaan yang bergerak dibidang jasa asuransi kerugian, khususnya kendaraan bermotor. Dalam bisnis asuransi umum/kerugian, surveyor sebagai salah satu sumber daya manusia dalam perusahaan asuransi memegang peranan penting dalam proses mengambil keputusan dan menggunakan teknologi yang ada tersebut.

Untuk menghadapi perkembangan dan perubahan itu dibutuhkan suatu manajemen kinerja di bagian surveyor, untuk menciptakan layanan yang simple dan memuaskan bagi para customer. Surveyor perlu meningkatkan kompetensinya agar dapat mengetahui karakteristik dan spesifikasi kendaraan yang akan disurvey sehingga dapat melakukan analisa dengan 
baik dan memberikan keputusan dengan benar sesuai dengan KPI (Key Performance Indcator) yang telah ditetapkan.

Untuk mengantisipasi perubahanperubahan lingkungan organisasi yang cepat dan dinamis, praktik manajemen kinerja baru dilakukan penyesuaian-penyesuaian melalui perbaikan berkelanjutan yang tanpa mengenal lelah dan tidak mempunyai akhir. Model manajemen kinerja yang terdiri dari empat tahap (perencanaan, implementasi, refleksi, dan kompensasi) dapat digunakan untuk perbaikan berkelanjuatan. Manajer dan supervisor bersama semua karyawan akan menggunakan praktik manajemen kinerja sebagai alat untuk memberikan kontribusi terhadap penentuan bentuk dan tujuan organisasi baru yang dinamis.

Hal ini membutuhkan sumber daya manusia yang kompeten yang memiliki semangat, kedisiplinan, dan integritas yang baik untuk mencapai tujuan perusahaan yang telah ditetapkan. Dengan integritas yang baik, seorang surveyor memiliki "value" di dalam perusahaan sehingga dapat diandalkan untuk bekerja sesuai yang telah ditentukan oleh perusahaan. Satu-satunya faktor yang menunjukkan keunggulan kompetitif dalam bisnis global adalah potensi sumber daya manusia (SDM) yang berkualitas. (Emron Edison, dkk, 2017: 3). Idealnya, setiap perusahaan memiliki budaya organisasi, yang merupakan sebuah sistem nilai yang terbentuk dari kesepakatan kolektif dari semua pihak dalam perusahaan atau organisasi. Kesepakatan disini adalah dalam hal cara pandang tentang bekerja dan unsurunsurnya.

Budaya yang kuat serta pengelolaan SDM yang baik dapat menjadi alat perusahaan untuk berkompetisi dengan pesaing. Karena dari budaya yang kuat ini akan meningkatkan perilaku yang konsisten yang dapat menciptakan efektifitas organisasi yang dipengaruhi oleh kinerja karyawan. Sedangkan bila budaya tersebut tidak kuat, maka tujuan organisasi akan berjalan ke arah yang salah. (Kotter \& Heskett, dalam Darmawiyanti, 2008). Jika budaya suatu organisasi tidak memberikan hal yang positif bagi organisasi tersebut, maka akan berdampak pada kinerja organisasi yang buruk, karena budaya perusahaan menginformasikan kepada karyawan tetang bagaimana perilaku karyawan yang semestinya. Budaya organisasi menjadi identitas sebuah organisasi yang mempengaruhi bagaimana orang-orang berbuat dalam organisasi. Sehingga jika budaya organisasi baik, maka tidak mengherankan jika anggota organisasi adalah orang-orang yang baik dan berkualitas pula.

\section{B. METODE}

Penelitian ini menggunakan metodologi kualitatif dengan pendekatan naratif, karakter alami (natural setting) dimana sumber data didapat secara 
langsung dan deskriptif. Analisis dilakukan secara naratif dan makna merupakan hal yang esensial.

\section{HASIL DAN PEMBAHASAN}

Penelitian ini dilakukan di bagian surveyor di kantor cabang Asuransi Astra Buana di wilayah Jatabek. Penelitian dilakukan menggunakan metode kualitatif dengan pendekatan naratif, yaitu mengamati proses kerja yang dilakukan oleh seorang surveyor sejak awal bergabung menjadi karyawan di PT. Asuransi Astra Buana.

Berdasarkan definisi dan fungsi surveyor, maka seorang surveyor harus memiliki kemampuan teknik otomotif, kemampuan analisa, dan kemampuan komunikasi yang baik sebagai dasar pelayanan (service) terhadap pelanggan. Berdasarkan analisa SWOT yang dilakukan, untuk memanfaatkan potensi yang ada untuk guna meraih peluang, Asuransi Astra Buana dapat melakukan strategi sebagai berikut:

a. Pemanfaatan budaya perusahaan yang baik dan kemampuan SDM yang dimiliki untuk menghasilkan layanan yang terbaik.

b. Pemanfaatan pengalaman manajemen dan dukungan dari grup untuk menambah jumlah pelanggan.

c. Pemanfaatan peraturan dan perundangan dengan integritas yang dimiliki utuk mendapatkan kepercayaan dari pelanggan.

\begin{tabular}{|c|c|c|}
\hline \multicolumn{3}{|c|}{ Analisa SWOT } \\
\hline \multirow{6}{*}{ EFAS } & STRENGTHS & WEAKNESS \\
\hline & Budaya perrsahaan yang baik & Kualitas pelayanan \\
\hline & Pengalaman manajemen & Sistem karyawan kontrak \\
\hline & Dukumgan perusahaan besar & Program pendidikan dan pelathan \\
\hline & Kemampuan SDM & Rate premi tingog \\
\hline & Memiliki integritas & \\
\hline OPPORTUNITIES & STRATEGISO & STRATEGIWO \\
\hline Meningkatnya industri otomoif & $\begin{array}{l}\text { Pemanfaatan budaya perusahaan } \\
\text { yang baik dan kemampuan SDM } \\
\text { untuk menghasilkan layanan yang } \\
\text { terbaik } \\
\end{array}$ & \begin{tabular}{|l|} 
Perencanaan perbaikan program pendidikan \\
dan pelathan yang berorientasipada \\
perbaikan kualitas layanan untuk \\
meningkatkan kinerja surveyor \\
\end{tabular} \\
\hline Perlaku bisnis & $\begin{array}{l}\text { Pemanffatan pengalaman } \\
\text { manajemen dan dukungan dari grup } \\
\text { untuk menambah jumlah pelanggan }\end{array}$ & $\begin{array}{l}\text { Perencanaan di masa mendatang untuk } \\
\text { mengangkat karyawan kontrak meniadi } \\
\text { karyawan tetap secara bertahap, untuk } \\
\text { mempertahankan budaya perusahaan yang } \\
\text { baik }\end{array}$ \\
\hline Customer & $\begin{array}{l}\text { Pemanfaatan peraturan dan } \\
\text { perundangan dengan imteggitas yang } \\
\text { dimiliki untuk mendapatkan } \\
\text { kepercayaan dari pelanggan } \\
\end{array}$ & \\
\hline \multicolumn{3}{|l|}{ Peraturan \& Perundangan } \\
\hline THREATS & STRATEGIST & STRATEGIWT \\
\hline Kondisi sosial, ekonomi, politik & $\begin{array}{l}\text { Pertahankan jumlah pelanggan dari } \\
\text { ancaman pesaing dan lembaga } \\
\text { keuangan lainnya melalui optimalisasi } \\
\text { budaya perusahaan, kemampuan } \\
\text { SDM, dan integitas } \\
\end{array}$ & $\begin{array}{l}\text { Antisisasi kondisi sosial ekonomidan } \\
\text { politik, dengan meningkatkan kemampuan } \\
\text { SDM yang dimiliki melalui program } \\
\text { pelatihan yang berorientasikepada layanan } \\
\text { pelangagan } \\
\end{array}$ \\
\hline Persaingan & $\begin{array}{l}\text { Pertahankan jumlah pelanggan } \\
\text { dengan memberi kemudahan } \\
\text { teknologi } \\
\end{array}$ & $\begin{array}{l}\text { Antisipasi persaingan daripesaing dengan } \\
\text { senantiasa mempertahankan kualitas } \\
\text { pelayanan }\end{array}$ \\
\hline Perubahan teknologi & $\begin{array}{l}\text { Memberikan pengetahuan kepada } \\
\text { pihak llar mengenai asurannsi dan isi } \\
\text { dariperianjan (polis) } \\
\end{array}$ & $\begin{array}{l}\text { Pengurangan sistem kontrak agar SDM } \\
\text { dapat lebih loyal dalam menghadapi } \\
\text { persaingan }\end{array}$ \\
\hline Perilaku piak ekstemal & & $\begin{array}{l}\text { Memberikan benefit dari produk asuransi } \\
\text { yang ditawarkan }\end{array}$ \\
\hline Lembaga kelangan laimnya & & \\
\hline
\end{tabular}

Memiliki budaya yang kuat merupakan pekerjaan besar bagi perusahaan dan menjadi keinginnan bagi setiap perusahaan. Prosesnya tentu tidak mudah, apalagi dengan terciptanya budaya yang sudah mengakar di lingkungan kerjanya yang dibawa dari masing-masing anggota organisasi. Perusahaan perlu mengambil tindakan dengan menyediakan dana dan 
menginvestasikan setiap individu untuk berkesempatan belajar.

Budaya yang unggul dapat diciptakan dengan membiasakan elemen-elemen pentingnya secara berkelanjutan. Proses ini tidak hanya diterapkan pada karyawan, tetapi juga pada para pemimpinnya, yang bisa dilakukan melalui pelatihan yang terencana dengan baik ataupun pembelajaran dengan berbagi pengalaman dengan perusahaan lain yang memiliki budaya yang kuat dan unggul.

Manajemen kinerja membutuhkan partispasi baik dari atasan maupun bawahan untuk mengembangkan program kerja menuju pencapaian tujuan organisasi. Dengan berpartisipasi secara efektif dalam kerangka kerja manajemen kinerja oleh berbagai pihak dalam perusahaan, maka diharapkan perusahaan berkinerja tinggi bukan sekedar impian semata.

\section{PENUTUP}

\section{Kesimpulan}

Setelah dilakukan pembahasan dan analisa terhadap hasil wawancara dan observasi mengenai bagaimana kinerja surveyor di PT. Asuransi Astra Buana, maka dapat diperoleh kesimpulan sebagai berikut:

1. Manajemen Kinerja Surveyor.
Pola manajemen kinerja surveyor sudah berjalan melalui metode PDCA. Perencanaan (Plan) disusun pada tengah tahun sebelumnya dalam bentuk activity plan, kemudian dikumpulkan dalam wadah planning cycle. Tindakan (Do) dalam bentuk komitmen (action) yang di launching di awal tahun berikutnya pada acara surveyor gathering. Monitor (Check) yang dilakukan oleh supervisor secara daily maupun mingguan terkait loading Bengkel, cost claim, panel replace dan panel repair, kemudian Review yang dilakukan secara mingguan (weekly) melalui meeting koordinator ataupun quarterly melalui meeting all surveyor jatabek. Hasil dari monitoring ini diterapkan (Action) kembali dalam pekerjaan sehari-hari sesuai target yang telah ditetapkan.

2. Budaya Perusahaan.

Budaya perusahaan (core value) di perusahaan ini berjalan dengan baik dan diterapkan dalam pekerjaan sehari-hari oleh surveyor. Untuk lebih mengaplikasikan budaya perusahaan ini, dibuat tagline 7sb (7 sexy behavior) yang terdiri dari:
a. Tersenyum.
b. Menyapa.
c. Menyebut nama. 
d. Antusias.

e. Informatif.

f. Helpful \& Solutif.

g. Personal touch.

Sehingga diharapkan surveyor dapat mengaplikasikan 7sb ini dalam pekerjaannya sehari-hari agar menciptakan suasana yang ramah, akrab dan memberikan pelayanan yang berkesan. Selain itu penerapan budaya perusahaan ini juga didukung dengan sistem yang digunakan oleh surveyor dalam bekerja, sehingga memudahkan proses kerja surveyor dan menciptakan layanan yang simple bagi pelanggan.

3. Implementasi penerapan budaya perusahaan dalam menunjang kinerja surveyor.

Secara keseluruhan, kinerja surveyor akan di evaluasi secara quarterly dan pada akhir tahun. Dari hasil evaluasi ini akan terlihat performance surveyor dan juga sebagai pertimbangan dalam menentukan target di tahun berikutnya. Walapun dari data yang ada kinerja surveyor belum sesuai target yang direncanakan, namun dari sisi layanan, customer Asuransi Astra Buana masih merasa puas dengan layanan yang diberikan surveyor Asuransi Astra Buana. Hal ini berkat implementasi budaya perusahaan yang diterapkan dalam pekerjaan sehari-hari dalam layanan kepada customer melalaui tagline 7sb.

Berdasarkan analisa SWOT yang dilakukan, maka salah satu strategi yang perlu dijalankan oleh Asuransi Astra Buana adalah memanfaatkan budaya perusahaan yang baik dan kemampuan SDM yang dimiliki untuk menghasilkan layanan yang terbaik pagi pelanggan dan juga meningkatkan kinerja surveyor. Dengan budaya layanan yang terbaik ini dapat memberikan nilai bagi para pelanggan dan para pelanggan pun dapat berperan sebagai "agen" dalam mempromosikan layanan yang mereka alami kepada orang lain yang akan berasuransi. Sehingga Asuransi Astra Buana memiliki nilai lebih untuk mempertahankan pelanggan yang sudah ada dan untuk mendapatkan pelanggan baru.

\section{Saran}

Berdasarkan hasil penelitian yang telah dilakukan maka penulis mengajukan beberapa saran untuk menyempurnakan keterbatasan yang ada, yaitu sebagai berikut:

1. Pengelolaan manajemen kinerja yang baik di surveyor agar dapat dipertahankan dan dijalankan secara konsisten.

Pemberian training/refreshment knowledge bagi surveyor adalah sesuatu yang mutlak diperlukan untuk mendapat 
tambahan pengetahuan baru disamping melakukan penyegaran terhadap pekerjaan sehari-hari yang telah dilakukannya dan juga dapat menjadi sarana diskusi untuk membahas permasalahan-

permasalahan yang ada di lapangan serta solusinya.

2. Untuk mendukung manajemen kinerja yang baik, diperlukan juga adanya innovasi dalam setiap pekerjaan. Terutama ide-ide agar perusahaan dapat tetap berjalan dengan baik, dapat memberikan layanan yang lebih mudah (simple) dan mengesankan (memorable) kepada pelanggan dan karyawan dapat memberikan manfaat bagi perusahaan.

3. Penggunaan peralatan kerja yang sesuai dengan kondisi dan teknologi saat ini, untuk mendukung kinerja surveyor dan juga dapat memberikan layanan yang mudah (simple) bagi pelanggan juga memberikan rasa nyaman (peace of mind).

4. Budaya perusahaan perlu dikenalkan kepada seluruh

\section{DAFTAR PUSTAKA}

Anwar Prabu Mangkunegara, A.A. (2005), Perilaku dan Budaya Organisasi, Refika Aditama, Bandung.

Asuransi Astra, (2016), Junior Surveyor Hard Competency Training, Jakarta.

Creswell, John W, (2015), Penelitian Kualitatif \& Desain Riset, Pustaka Pelajar, Yogyakarta.

Emron Edison, dkk, (2017), Manajemen Sumber Daya Manusia, Alfabeta, Bandung.

Mia Lasmi Wardiah, (2016), Teori Perilaku dan Budaya Organisasi, Pustaka Setia, Bandung

Sugiyono, (2017), Metode Penelitian Kuantitatif, Kualitatif, dan R\&D, Alfabeta, Bandung. 